\title{
NOTES ON DISTRIBUTION AND HABITS OF SOME OF THE BIRD-FLIES, HIPPOBOSCID丑.
}

\author{
By Charles W. Johnson,
}

\section{Boston Society of Natural History.}

The following notes on this interesting group of flies have been brought together in the hope of thereby encouraging ornithologists to observe more closely the occurence of these insects on the various species of birds. While the wide distribution and great diversity of hosts frequented by one species seems somewhat at variance with the distribution of other insects as well as their hosts, it is impossible with the limited material and data at hand to arrive at any other conclusion regarding the species. Highly specialized forms always lose many of the distinguishing specific characters present in the species of the higher groups less restricted in their habits. Living as these flies do under similar and uniform conditions, notwithstanding their wide distribution, they would naturally show but little variation.

The occurence of the same species of fly upon non-migrating birds confined both to the tropical and boreal regions would indicate that they are naturally transmitted from one to the other by the migratory species; and the interesting example of phoresy recorded below shows how the various species of the wingless Mallophaga are also distributed.

One of the peculiar habits of these flies, and one which probably accounts for so few of them being taken by ornithologists, is that they are rarely seen while the bird is warm, but as the dead bird becomes cold they dart from it as if terror-stricken at losing their host, for if another cannot be found soon, it probably means death. If in this quick flight they happen to alight on one's clothes, there is a possibility of capturing them, if caught firmly between the thumb and finger, for their smooth, flattened bodies slip easily through one's fingers and when once they escape they are rarely seen again, as they dart into any little crevice that offers protection.

Their method of reproduction admits of no great increase, producing but one large egg at a time, which develops into a 
peculiar larval condition within the parent, and pupating at birth. The decrease in the number of birds will undoubtedly diminish these flies, which deserve a great deal of careful biological study, for our knowledge of the group is still very inadequate.

The following records are in part based upon specimens in the Museum of Comparative Zoölogy, Boston Society of Natural History, and the author's collection.

\section{Ornithoica confluenta (Say).}

Ornithomyia confluenta Say, Jour. Acad. Nat. Sci. Phila., III, 103, 1823.

Ornithomyia confluens Wied., Auss. Zw., II, 611, 1830.

Ornithomyia vicina Walker, List Dipt., IV, 1144, 1849.

Ornithoica confluenta Speiser, Ann. Museo. Civ., XX (2d ser.) 558, 1899; Ent News, XVIII, 103, 1907.

Ornithoica confluens Aldrich, Catl., 655, 1905.

Say recorded this species from "Ardea candidissima,"-Snowy Heron (Egretta candidissima). No locality is given, and it may have been collected in "Pa.," "or west of the Missouri River." Wiedemann gives Pennsylvania. Walker's $O$. vicina was from "Jamaica, on Ephialtes grammicus" [Jamaica owl] (Gosse Coll.); also on Psittacus leucocephalus. Nothing further regarding the habits of this species appeared until 1878. Osten Sacken in his catalogue of Diptera, page 263, says: "Ornithomyia confluenta Say will, I suppose, form a new genus, on account of its peculiar venation. An apparently diffierent species of the same group was found by Mr. Wm. Holden on Accipiter fuscus near San José Cal." A study of this specimen in the Museum of Comparative Zoölogy shows no character to separate it from specimens referable to $O$. confluenta. There are also in the above Museum four specimens from Cuba, one collected by Poey and three by Gundlach. There is in the old collection of the Boston Society of Natural History a specimen marked "Mass."

The latest and most interesting capture of this species was that of two specimens by Mr. W. S. Brooks at Wilson Mills, Oxford County, Maine, Nov. 4, 1921, from the Canada Jay 
(Perisoreus canadensis). It was these specimens from a nonmigratory bird of Canadian life-zone that led to a study of this species and the finding of an almost parallel case in the distribution and habits of Ornithomyia anchineuria. Some specimens are slightly darker than others and vary from 2 to $2.5 \mathrm{~mm}$. The wing is shown in figure 1 , and the following species in figure 2 .
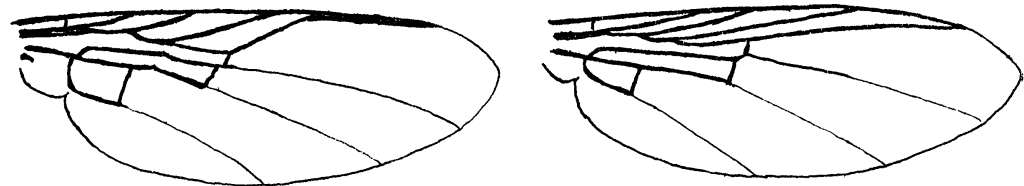

Fig. 1. Wing of Ornithomyia confuenta at left; of O. anchineuria at right.

Ornithomyia anchineuria Speiser.

Ornithomyia pallida Say, 1823, nec Latreille, 1811.

Ornithomyia anchineuria Speiser, Zeitschr. f. Hym. u. Dipt., $1905, \mathrm{~V}, 348$.

Say's type was taken on the Bluebird, "Sylvia sialis." No locality is mentioned. Wiedemann gives "Pennsylvania," and in Aldrich's Catalogue is "West of the Mo. River." In Smith's Insects of New Jersey, 1899, p. 699, I recorded it from the Bobolink or Reed-bird (Dolichonyx oryzivorus) and Red-winged Blackbird (Agelaius phoniceus). The specimens were collected by Mr. Charles Liebeck along the Delaware River below Philadelphia, Aug. 19 to Sept. 27, 1892-97. A specimen was taken on a Hermit Thrush (Hylocichla guttata pallasii) at Clifton, Pa., Oct. 19, 1897, by Mr. C. A. Voelker. A specimen was also obtained from a Robin (Planesticus migratorius) at Southbridge, Mass., Aug. 18, 1914, by Mr. S. W. Bromley, and from a young Junco (Junco hyemalis) at Woodstock, Vt., Aug. 1911, by Mr. A. P. Morse. In the Museum of Comparative Zoölogy is a specimen from the Red Crossbill (Loxia curvirostra minor) collected at North Bay, Onatrio, Sept. 7, 1896, by G. S. Miller, Jr., and from the Catbird (Dumetella carolinensis), at Worthington, Mass. Another specimen in the same Museum was collected by Mr. W. S. Brooks at Ellis Bay, Anticosti Island, Sept. 3, 1919. from a new Jay (Perisoreus barbouri) allied to the Canada Jay, 
This specimen has attached to it two Mallophaga, one on each side of the abdomen just back of the posterior edge of the first segment; in the dried specimen they extend beyond the end of the fly's abdomen, with the ends of the Mallophaga touching each other. It is an interesting example of phoresy and shows how many of the Mallophaga are probably distributed. ${ }^{1}$

On Aug. 29, 1921, Mr. A. B. Fuller obtained two specimens from the Savannah Sparrow (Passerculus sandwichensis savanna) at Essex, Mass. One of the flies had attached to it a pupa, black and polished in appearance, but when enlarged twentyfive diameters it shows an irregular mosaic-like pattern. At one end there is a slight contraction, forming four or five slight nodes. Its length is $2.5 \mathrm{~mm}$., while the total length of the dried fly is $4 \mathrm{~mm}$. In a recent "Annotated List of the Diptera or Oregon," by Cole and Lovett (Proc. Cal. Acad. Sci., 1921, 4th ser., XI, 344), this species is recorded from "Upper Alsea Valley, Benton Co., on Steller's Jay." Coquillett records it from Washington D. C., to California.

Except for size, I see little to separate this species from the European O. avicularia Linn., and it is probably what Van der Wulp had before him when he recorded the latter from Wisconsin (Tijdsch. v. Ent., XII, 80, 1869). As Coquillett suggests (Ent. News, XVIII, 290, 1907), it may represent one holarctic species. The $O$. avicularia also frequents many species of birds, including hawks, owls, woodpeckers, herons, ravens, jays, partridges, peacocks, crossbills, sparrows, skylarks etc.

\section{Olfersia albipennis Say.}

It is a question whether $O$. albipennis and what we are calling $O$. ardece are not one and the same species, but whether it is the same as the European species is still another question. When the light strikes the wings at a certain angle, especially when they overlap each other, they are often decidedly whitish in color, hence Say's name. As it is an older name than $O$. ardece,

1This specimen was recorded by Nathan Banks in Psyche, Vol. 27, p. 20,1920, and by W. L. McAtee in Ent. News, Vol. 33, p. 20, 1922. The bird however was not mentioned. 
1922] Johnson-Notes on Distribution and Habits of Bird-Flies 83

I am using it for the American species. It has been taken from the following species of birds:

Great Blue Heron (Ardea herodias) T. Say.

Black-crowned Night Heron (Nycticorax nycticorax). Alston, Boston, Mass., Aug. 1, '12; Hampton, N. H., May 13, '17 (S. A. Shaw); Delaware River, below Philadelphia, Oct. 15 '96 (C. Liebeck).

Little Blue Heron (Florida ccerulea). Bristol Isl., Delaware River (Fowler).

White Heron or Egret (Herodias egretta). St. Augustine, Nov. 8, '87.

American Bittern (Botaurus lentiginosus). Delaware River below Philadelphia, Sept. 13-Oct. 12,'85 (C. Liebeck).

Least Bittern (Ixobrychus exilis). Delaware River below Philadelphia, Sept. 18, (C. Liebeck).

\section{Olfersia americana (Leach)}

This species is known to frequent the following birds:

Great Horned Owl (Bubo virginianus). Wenham, Mass., Dec. 2,'10 (Dr. J. C. Phillips), Dover, Mass., Dec. 24,'94 (A.

P. Morse), San José, Cal. (W. Holden).

Barn Owl (Aluco pratincola). San José, Cal. (W. Holden).

Long-eared Owl (Asio wilsonianus). Hampton, N. H., Apr. 9, '09 (S. A. Shaw).

Barred Owl (Strix varia). Framingham, Mass., Nov. 1,'10 (C. A. Frost).

Screech Owl (Otus asio floridanus). St. Augustine, Fla. (C. W.J.)

Western Screech Owl (Otus mecallii). Calif. (M. C. Z). Red-shouldered Hawk (Buteo lineatus). Wenham, Mass., Aug. 14,'14 (J. C. Phillips), Sherborn, Sept. 21,'98,(A.P.Morse); Dunmore Lake, Vt. (C. E. Brown).

Red-tailed Hawk (Buteo borealis). Illinois (M. C. Z.). Broad-winged Hawk (Buteo platypterus). Texas (G. H. Ragsdale).

Pigeon Hawk (Falco columbarius). (B. S. N. H.). 
Ruffed Grouse (Bonassa umbellus). Liberty Hill, Conn., Oct. 1896 (O. Bangs).

\section{Olfersia sp.}

From Chuck-wills-widow (Antrostomus carolinensis), St. Augustine, Fla. (C. W. J.).

\section{Ornithoctona erythrocephala (LEACH)}

This has been found on the following species of birds: Red-tailed Hawk (Buteo borealis). Cuba (M. C. Z.). Broad-winged Hawk (Buteo platypterus). Cuba (M. C. Z.). Sparrow Hawk (Falco sparverius). Porto Rico (Coquillett). Ruddy Quail-dove (Geotrygon montana). Holguin, Cuba (M. C. Z.).

Yellow-crowned Night Heron (Nyctanassa violacea). Dominica, May 25,'01 (O. Bangs).

Pigeon Hawk (Falco columbarius). Metis, Quebec, collected by L. M. Terrill.

The last record, received through Mr. Albert F. Winn, is especially interesting. Although Osten Sacken recorded this fly from Quebec, this is the first record of a host north of the West Indies. Mr. Terrill captured the hawk on her nest and seven specimens of the fly were taken. Since writing the above Jos. Ouellet informs me that he has taken this species on the American Bittern, near Montreal, Aug. 1902.

\section{Pseudolfersia fumipennis (SAHLBERG)}

(P. maculata Coquillett).

From the Fish Hawk or Osprey (Pandion halicetus carolinensis). Cape May, N. J., Aug.; Lahaway, N. J., Apr. 1 (J. T. Brakeley); St. Augustine, Fla. (C. W. J.); Sand Point, La., and Cuba (Mus. Comp. Zool.); Bald Eagle (Haliaeetus leucocephala). Hampton, N. H., May 17,'05 (S. A. Shaw); and Loon (Gavia immer). Wisconsin (Coquillett). 


\section{Pseudofersia spinifer (LEACH)}

Taken on the Florida Cormorant (Phalacrocorax auritus floridanus) at Great Sale Key, Bahams, July 17,'05, by Dr. G. M. Allen. A widely distributed species of the tropics, frequenting the Man-o'-War-Bird (Fregata aquila), Gannets and Black Vulture.

\section{NOTES ON NEOTTIGLOSSA TRILINEATA KIRBY (HEMIPTERA, PENTATOMID E) ${ }^{1}$}

\section{By Roland F. Hussey}

In Richardson's "Fauna Boreali-Americana" (Vol. 4, 1837, p. 276, pl. vi, figs. 6, 6a), W. Kirby described and figured a Pentatoma trilineata, from one specimen "taken in the road from New York to Cumberland House" [Saskatchewan], and proposed for it a new subgenus, Neottiglossa, which he characterized, in the following words:

"Nose shorter than the cheeks. Bed of the promuscis elevated on each side at the base.

"In the typical Pentatomoe, the part which I regard as analogous to a nose is of the same length with the two lateral lobes of the front, and the base of the cavity in which the promuscis reposes when unemployed is not so elevated."

Whatever may be said of this generic diagnosis, whose incompleteness led to the redescription of the genus under different names by Dohrn (1860) and by Fieber (1861), Kirby's description of Pentatoma trilineata serves amply for the identification of the species, and it is surprising that it has not been better understood. Dallas (List of Hemip., i, 1851, p. 224) records the species from Hudson's Bay and from Nova Scotia. Uhler (Proc. Bost. Soc. Nat. Hist., xiv, 1871, p. 96) placed trilineata as a synonym of Neottiglossa undata Say, in which he was followed by Stâl (Enum. Hem., ii, 1872, p. 18). A few years later, Uhler (Bull. U. S. Geol. Geogr. Surv., iii, 1877, p. 401) separated the two species, 

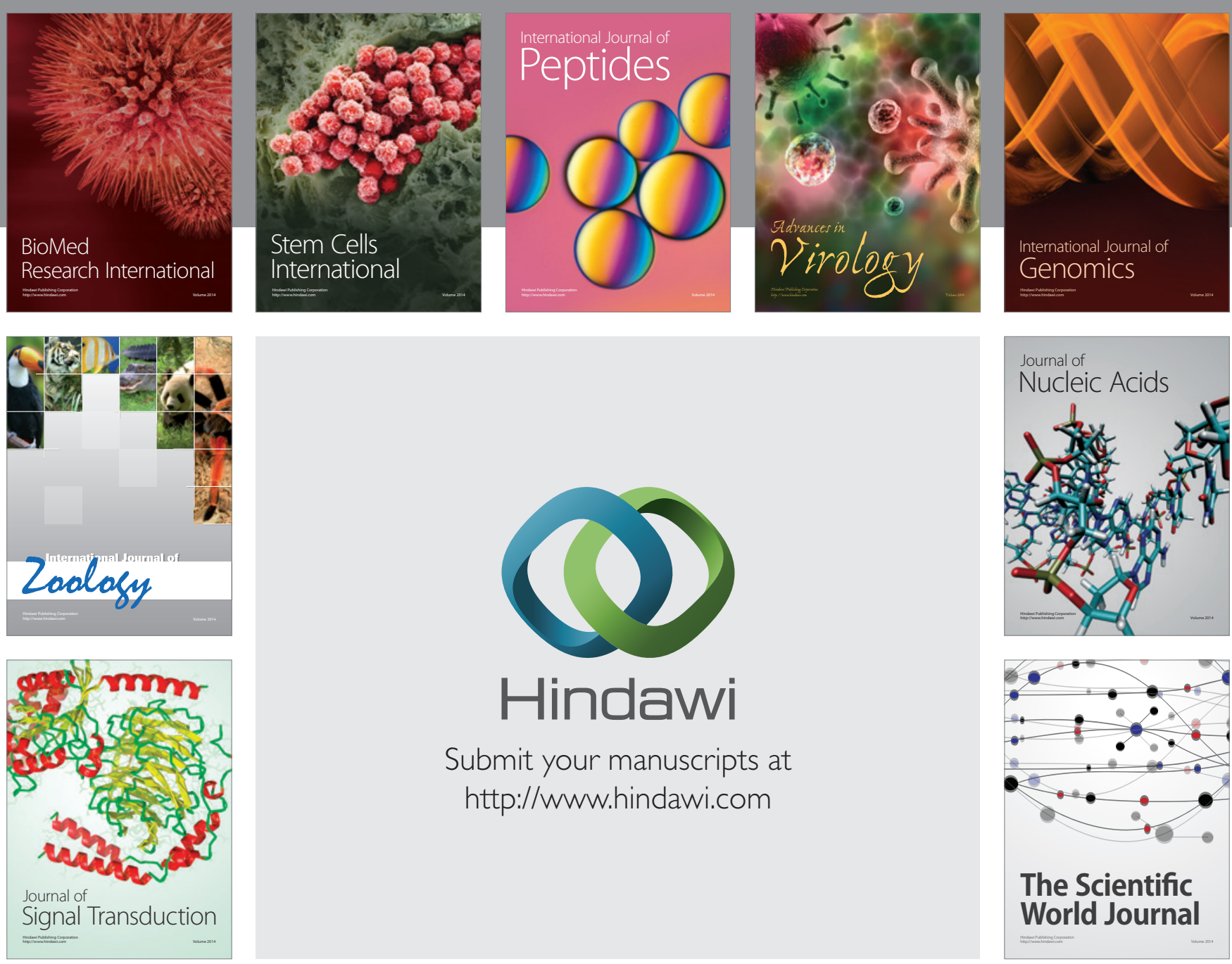

Submit your manuscripts at

http://www.hindawi.com
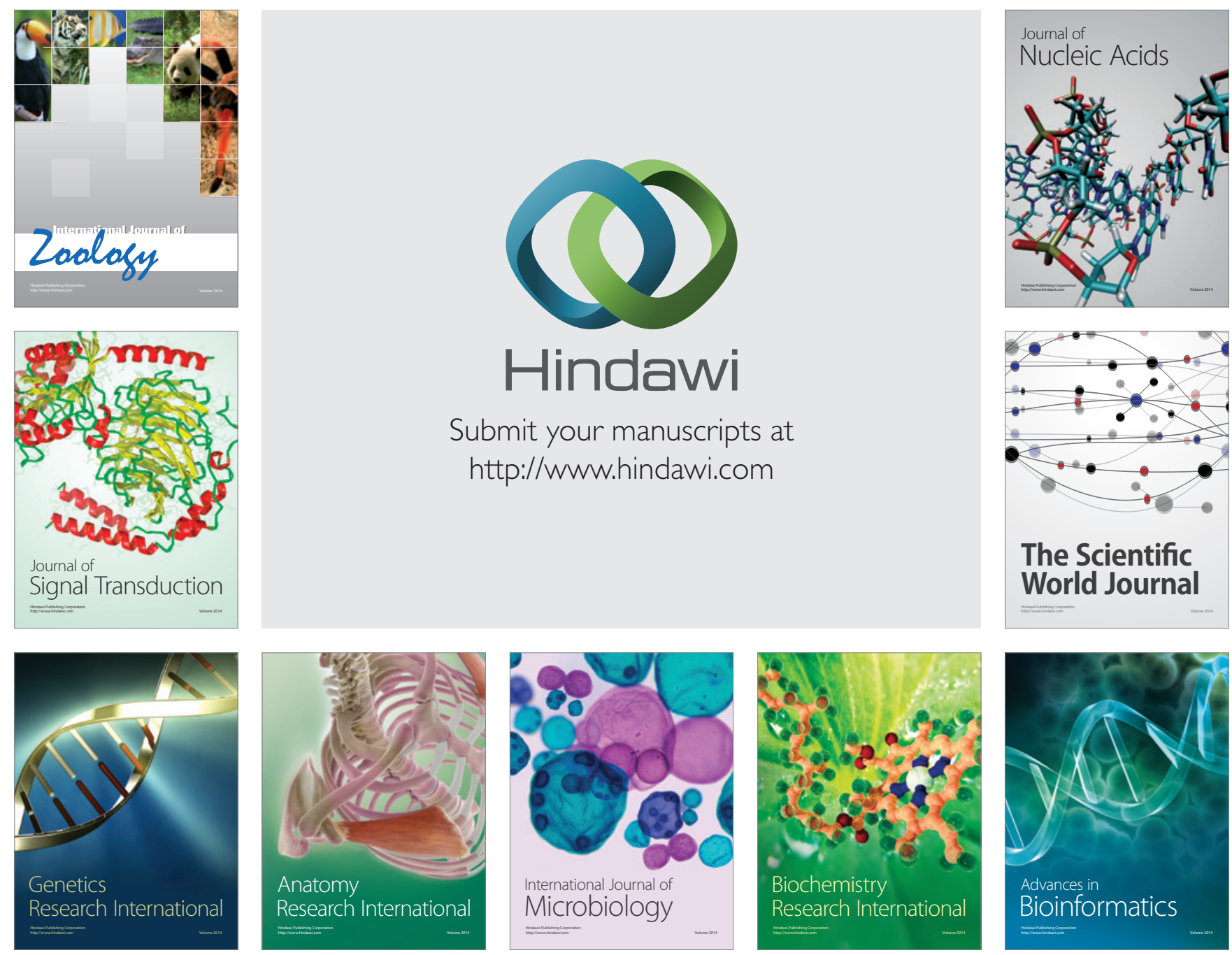

The Scientific World Journal
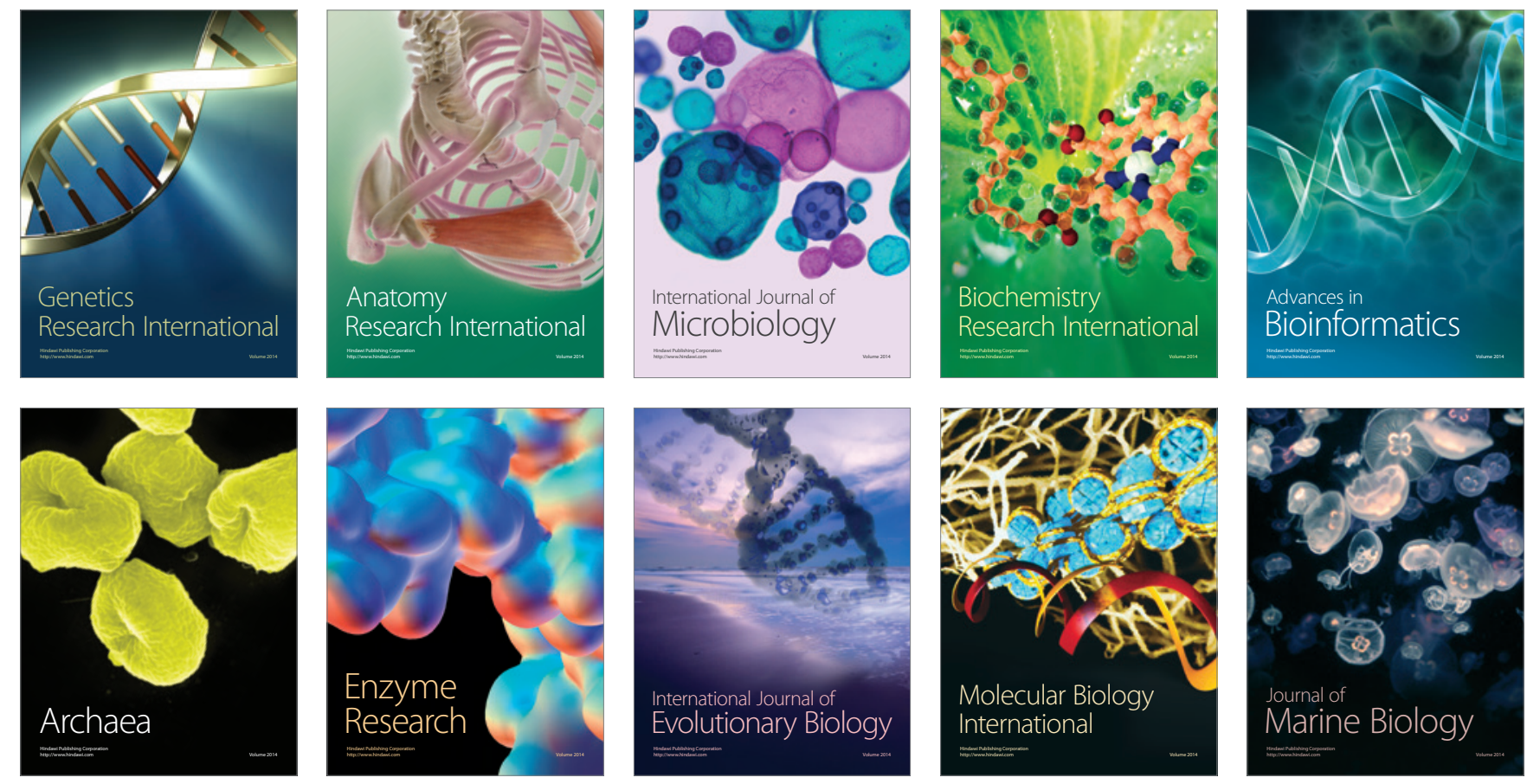